\title{
Schikken, of toch maar niet?
}

\section{Een onderzoek naar het verschil in werking tussen een rechterlijke uitspraak en een schikking neergelegd in een proces-verbaal}

\author{
$M r . M . W . K n i g g e^{*}$
}

\section{Inleiding}

Voor partijen kan het grote voordelen hebben om tijdens een procedure alsnog tot een schikking te komen. Zij verkrijgen hierdoor sneller duidelijkheid en besparen de kosten die verbonden zijn aan verder procederen. Voorts zal het voor de onderlinge verhouding veelal beter zijn als partijen er samen uitkomen. ${ }^{1}$ Om een executoriale titel te verkrijgen is het voor partijen niet nodig dat de rechter uitspraak doet. Art. 87 lid 3 van het Wetboek van Burgerlijke Rechtsvordering (Rv) biedt de mogelijkheid om een tijdens een comparitie tot stand gekomen schikking in een proces-verbaal neer te leggen. De uitgifte van dit proces-verbaal geschiedt in executoriale vorm. Onder $\mathrm{KEI}$ is deze bepaling vrijwel ongewijzigd terechtgekomen in art. 30m Rv (nieuw). Belangrijk daarbij is wel dat dit nieuwe art. $30 \mathrm{~m} \mathrm{Rv}$ is geplaatst in de eerste titel ('Algemene bepalingen') en niet meer in de tweede, zodat deze bepaling ook zal gelden in verzoekprocedures. ${ }^{2}$ Hieronder zal steeds enkel worden verwezen naar art. 87 lid $3 \mathrm{Rv}$; deze bijdrage is echter evenzeer relevant voor het nieuwe art. $30 \mathrm{~m} \mathrm{Rv}$.

Hoewel het proces-verbaal in executoriale vorm wordt uitgegeven, kunnen er ten opzichte van een rechterlijke uitspraak wel degelijk nadelen zijn verbonden aan een schikking die wordt neergelegd in een proces-verbaal. Uit een arrest van de Hoge Raad van 27 november 2015 blijkt dat voor vorderingen die voortvloeien uit een in een proces-verbaal neergelegde schikking over het algemeen een kortere verjaringstermijn geldt dan voor vorderingen neergelegd in een rechterlijke uitspraak. ${ }^{3}$ Een schikking neergelegd in een proces-verbaal kan volgens de Hoge Raad niet worden aangemerkt als een rechterlijke uitspraak, zodat de twintigjarige verjaringstermijn van art. 3:324 lid 1 van het Burgerlijk Wetboek (BW) niet van toepassing is. In plaats daarvan zal meestal de vijfjarige termijn van art. 3:307 lid $1 \mathrm{BW}$ gelden.

In dit artikel wordt onderzocht in hoeverre er nog andere nadelen verbonden zijn aan een in een proces-verbaal neerge-

\footnotetext{
* Mw. mr. M.W. Knigge is universitair docent Burgerlijk recht aan de Universiteit Leiden.

Met dank aan prof. mr. H.B. Krans voor zijn commentaar op een eerdere versie van dit artikel.

1. Zie over de redenen die partijen en hun advocaten geven om te willen schikken, J. van der Linden, De civiele zitting centraal: informeren, afstemmen en schikken (diss. Tilburg), Deventer: Kluwer 2010, p. 37-39.

2. Zie ook Kamerstukken II 2014/15, 34059, 3, p. 73 (MvT).

3. HR 27 november 2015, ECLI:NL:HR:2015:3423, NJ 2016/3, r.o. 3.3.2.
}

legde schikking ten opzichte van een rechterlijke uitspraak. Voor partijen kan dit relevant zijn bij hun afweging al dan niet te schikken. Hiertoe zullen hieronder de rechtsgevolgen verbonden aan een schikking neergelegd in een proces-verbaal worden vergeleken met die van een rechterlijke uitspraak. Voor zover uit deze vergelijking knelpunten naar voren komen, worden suggesties gedaan hoe partijen deze in hun schikking kunnen ondervangen (par. $2 \mathrm{t} / \mathrm{m} \mathrm{6}$ ). Daarna wordt in paragraaf 7 kort ingegaan op een alternatief voor het in een proces-verbaal neerleggen van een schikking.

\section{De schikking in een proces-verbaal: een vaststellingsovereenkomst}

Hoewel zowel een rechterlijke uitspraak als een schikking neergelegd in een proces-verbaal een executoriale titel oplevert, bestaan er voor het overige grote verschillen tussen beide. Dat beide een fundamenteel ander karakter hebben, blijkt uit het in de inleiding genoemde arrest van de Hoge Raad van 27 november 2015 .

In deze zaak waren partijen tijdens een comparitie in een eerdere procedure een schikking overeengekomen, die zij in een proces-verbaal hadden vastgelegd. De schikking hield onder meer in dat de man aan de vrouw uiterlijk op 20 juli 2008 een bedrag van $€ 95.000$ zou betalen. De man kwam deze overeenkomst niet na en beriep zich na vijf jaar op verjaring. De vrouw meende echter dat in dit geval niet de vijfjaarstermijn van art. 3:307 lid $1 \mathrm{BW}$ van toepassing was, maar de termijn van twintig jaar van art. 3:324 lid $1 \mathrm{BW}$; de schikking in het proces-verbaal zou hebben te gelden als een rechterlijke uitspraak. Noch de voorzieningenrechter, noch het hof, noch de Hoge Raad ging in dit standpunt van de vrouw mee.

Ter motivering van zijn oordeel benadrukte de Hoge Raad dat indien tijdens een comparitie van partijen een schikking tot stand komt en hiervan een proces-verbaal wordt opgemakkt, in dit proces-verbaal de overeenkomst van partijen wordt vastgelegd. De vastlegging van een schikking in een proces-verbaal kan volgens de Hoge Raad niet worden aangemerkt als een rechterlijke uitspraak. De omstandigheden dat de uitgifte van het proces-verbaal op grond van art. 87 lid $3 \mathrm{Rv}$ geschiedt in executoriale vorm en dat de afgifte geschiedt door 
een rechter zijn voor de Hoge Raad onvoldoende om tot een ander oordeel te komen. ${ }^{4}$

Niet de vorm (een in executoriale vorm door een rechter afgegeven proces-verbaal), maar de inhoud (een overeenkomst van partijen) is kortom beslissend. ${ }^{5}$ Een schikking neergelegd in een proces-verbaal is een overeenkomst en de rechtsgevolgen worden dan ook bepaald door het overeenkomstenrecht.

Meer specifiek kan een schikking neergelegd in een procesverbaal over het algemeen worden gekwalificeerd als een vaststellingsovereenkomst. De bepalingen van titel 15 van Boek 7 BW zijn hierop dus van toepassing. Deze titel kent een aantal eigenaardigheden, waarop partijen bij het sluiten van hun overeenkomst bedacht moeten zijn. Hieronder wordt nader op een aantal verschillen in werking tussen een rechterlijke uitspraak en een schikking ingegaan, waarbij enkele van deze eigenaardigheden aan bod komen.

\section{Dispositieve werking}

\subsection{Rechterlijke uitspraak versus schikking in een proces-verbaal}

Een vaststellingsovereenkomst heeft enkel dispositieve werking. Deze dispositieve werking houdt in dat de rechtstoestand waaraan partijen zich bij de vaststellingsovereenkomst jegens elkaar hebben gebonden niet door die enkele overeenkomst bestaat, maar dat deze rechtstoestand door middel van uitvoeringshandelingen tot stand gebracht moet worden. Indien partijen bijvoorbeeld een geschil hebben over de eigendom van een stuk grond en zij in een vaststellingsovereenkomst neerleggen dat A eigenaar van deze grond is, maakt deze enkele overeenkomst A nog geen eigenaar. Hiervoor is nodig dat de grond ook aan A geleverd wordt. ${ }^{6}$ Deze dispositieve werking blijkt uit art. 7:901 lid $1 \mathrm{BW}$, waarin is bepaald dat de totstandkoming van de vaststelling is gebonden aan de vereisten waaraan moet worden voldaan om de met de beslissing beoogde rechtstoestand, uitgaande van die waarvan zij mogelijk afwijkt, tot stand te brengen. Partijen zijn verplicht om mee te werken aan het tot stand brengen van de beoogde rechtstoestand: lid 2 van art. 7:901 BW bepaalt dat elk van de partijen jegens de andere verplicht is te verrichten hetgeen van haar zijde nodig is om aan de vereisten voor de totstandkoming van de vaststelling te voldoen.

Voor partijen die overwegen door middel van een schikking tijdens een comparitie een einde te maken aan hun geschil, is het van belang zich bewust te zijn van dit verschil in werking met een rechterlijke uitspraak. Een schikking waarin A als eigenaar van een stuk grond wordt aangewezen, vereist leveringshandelingen door partijen. Indien in de schikking

4. HR 27 november 2015, ECLI:NL:HR:2015:3423, NJ 2016/3, r.o. 3.3.2.

5. Vgl. A-G Wesseling-van Gent in haar conclusie bij dit arrest, ECLI:NL:HR:2015:3423, nr. 2.14; vgl. ook de hieronder in par. 7 besproken uitspraak HR 19 november 1982, ECLI:NL:HR: 1982:AG4483, NJ 1983/494, m.nt. E.A.A. Luijten, r.o. 3.3, die draaide om een op de voet van art. $819 \mathrm{Rv}$ in een echtscheidingsbeschikking opgenomen convenant van partijen.

6. Zie voor de onderbouwing van de keuze voor het dispositieve stelsel Kamerstukken II 1982/83, 17779, 3, p. 33-35 (MvT). beide partijen voor een gedeelte gelijk krijgen ( $\mathrm{A}$ is eigenaar van de ene helft van het stuk grond en $B$ van de andere helft), zijn in principe zelfs twee leveringen vereist; zowel A als B moet het aan haar toegewezen gedeelte geleverd krijgen. In de parlementaire geschiedenis wordt gelukkig het praktische standpunt ingenomen dat partijen in een dergelijk geval kunnen volstaan met het opmaken van één notariële akte waarin zij de vaststellingsovereenkomst neerleggen, en het inschrijven van deze akte in de openbare registers. ${ }^{7}$ Voor een rechterlijke uitspraak geldt dit alles niet: met het in kracht van gewijsde gaan van de uitspraak dat A eigenaar is, staat deze eigendom tussen partijen vast; uitvoeringshandelingen zijn niet vereist. Wel zal het, gelet op art. 3:24 BW, voor A verstandig zijn de uitspraak op de voet van art. 3:17 lid 1 onder e BW in de openbare registers in te schrijven. ${ }^{8}$

Hoewel er dus een principieel verschil in werking bestaat tussen een rechterlijke uitspraak en een schikking neergelegd in een proces-verbaal, doet dit verschil zich in de praktijk lang niet altijd gevoelen. De gevolgen van de dispositieve werking van de vaststellingsovereenkomst worden door art. 7:901 lid 3 BW sterk gemitigeerd. Uit dit lid blijkt dat voor zover aan de vereisten voor de totstandkoming van de vaststelling kan worden voldaan door een verklaring van partijen of een hunner, deze verklaring in de vaststellingsovereenkomst besloten wordt geacht, tenzij uit de overeenkomst anders voortvloeit. Indien tussen partijen bijvoorbeeld een geschil bestaat over de eigendom van een roerende zaak en zij leggen in een vaststellingsovereenkomst neer dat A eigenaar is, brengt de dispositieve werking ook hier weer mee dat de zaak aan A geleverd zal moeten worden, voordat zij eigenaar is. Verschil met de levering van onroerende zaken is dat levering in dit geval op grond van art. 3:115 BW veelal zal kunnen geschieden door middel van een tweezijdige verklaring. Art. 7:901 lid 3 BW brengt dan mee dat een dergelijke tweezijdige verklaring in de vaststellingsovereenkomst besloten wordt geacht. ${ }^{9}$ Met het sluiten van de vaststellingsovereenkomst is hieraan meteen uitvoering gegeven; de beoogde rechtstoestand ( $\mathrm{A}$ is eigenaar) wordt direct tot stand gebracht.

Ook indien partijen bij vaststellingsovereenkomst een onzekerheid of geschil ten aanzien van vorderingsrechten beëindigen, kan de beoogde rechtstoestand over het algemeen door middel van een enkele verklaring tot stand worden

7. Kamerstukken II 1982/83, 17779, 3, p. 37 (MvT). In de literatuur bestaat discussie over de vraag hoe deze akte dan moet worden gezien: als een leveringsakte of als een andersoortige akte waarmee de vaststelling tot stand wordt gebracht. Zie P.E. Ernste, Bindend advies (diss. Nijmegen), Deventer: Kluwer 2012, p. 64-65; W. Snijders, 'Bekrachtiging en aanverwante rechtsfiguren', WPNR 2003/6547, p. 705-706, par. 12; L.C.A Verstappen, 'Registratie van verkrijgingsverjaringen', WPNR 2013/6970, p. 279, par. 10; A.C. van Schaick, 'De rechtsgevolgen van de vaststellingsovereenkomst', WPNR 2013/6985, p. 646-649; L.C.A. Verstappen, 'Naschrift', WPNR 2013/6985, p. 649-652.

8. Indien A nalaat om de uitspraak op de voet van art. 3:17 lid 1 onder e BW in te schrijven, kan deze uitspraak op grond van art. 3:24 lid $1 \mathrm{BW}$ bijv. niet worden tegengeworpen aan een derde aan wie B het stuk grond ondanks de rechterlijke uitspraak heeft overgedragen, tenzij deze derde de rechterlijke uitspraak kende. Op deze manier kan A de eigendom van het stuk grond alsnog verliezen.

9. Zie ook Kamerstukken II 1982/83, 17779, 3, p. 37 (MvT). 
gebracht. Indien partijen bijvoorbeeld overeenkomen dat $\mathrm{A}$ een schadevergoeding van $€ 10.000$ aan $B$ verschuldigd is, kan in de vaststellingsovereenkomst een afstand van recht besloten worden geacht, voor zover B aanspraak meende te hebben op een hoger bedrag. ${ }^{10}$

\subsection{Knelpunten en mogelijke oplossingen}

Als gevolg van art. 7:901 lid 3 BW levert de dispositieve werking van de vaststellingsovereenkomst in de meeste gevallen geen problemen op. Art. 7:901 lid 3 BW kan echter geen toepassing vinden indien aan de overdracht, het tot stand brengen of het afstand doen van een bepaald recht vormvoorschriften verbonden zijn. Dit is met name aan de orde in geschillen over de rechtstoestand van registergoederen. In dit type zaken moeten partijen die overwegen om tijdens een comparitie een schikking aan te gaan, erop bedacht zijn dat uitvoeringshandelingen vereist zijn om de door hen gewenste rechtstoestand tot stand te brengen.

Problemen kunnen ontstaan indien de wederpartij ondanks de schikking niet meewerkt aan de totstandkoming van de vaststelling. Een partij die bij een schikking is aangewezen als eigenaar van een stuk grond heeft er belang bij dat binnen bekwame tijd uitvoering wordt gegeven aan de schikking; zolang niet geleverd is, heeft zij slechts een verbintenisrechtelijke aanspraak op de grond. Anders dan wanneer op grond van een rechterlijke uitspraak voor partijen een verplichting tot het gezamenlijk opmaken van een akte bestaat, kunnen partijen in geval van een schikking niet profiteren van art. 3:300 lid 2 BW. De rechter heeft niet de mogelijkheid om te bepalen dat het proces-verbaal in de plaats van de akte of een deel daarvan zal treden. Medewerking van beide partijen aan de uitvoeringshandelingen is kortom vereist.

Om de kans te verkleinen dat de wederpartij niet meewerkt, kan het verstandig zijn om in de schikking al zo concreet mogelijke afspraken over de uitvoeringshandelingen op te nemen. In geval van de levering van een stuk grond kunnen dit bijvoorbeeld afspraken zijn over het (uiterlijke) moment van levering, de notaris die benaderd zal worden, enzovoort. Partijen kunnen daarbij een boetebeding opnemen voor het geval niet wordt meegewerkt.

Een andere oplossing is dat de wederpartij in de schikking een volmacht verleent voor het verrichten van de uitvoeringshandelingen aan de partij die hier belang bij heeft. Volmachtverlening kan vormvrij geschieden, zelfs als de rechtshandeling waarvoor de volmacht wordt verleend wel aan een vormvoorschrift is gebonden. ${ }^{11} \mathrm{Wel}$ is gelet op art. 3:68 BW vereist dat de inhoud van de uitvoeringshandelingen reeds voldoende nauwkeurig vaststaat, anders ontstaat strijd met het verbod van Selbsteintritt.

10. Zie ook Kamerstukken II 1982/83, 17779, 3, p. 37 (MvT).

11. Asser/Van der Grinten \& Kortmann 2-I 2004/26; A.C. van Schaick, Volmacht (Mon. BW B5), Deventer: Kluwer 2011, p. 23-25. Voorbeelden van uitzonderingen zijn te vinden in art. 3:260 lid 3 en 3:275 BW.

\section{Aantastingsmogelijkheden}

\subsection{Rechterlijke uitspraak versus schikking in een proces-verbaal}

Tussen een rechterlijke uitspraak en een in een proces-verbaal neergelegde schikking bestaan grote verschillen op het punt van de aantastingsmogelijkheden. In een bepaald opzicht bestaan voor een partij ruimere mogelijkheden om op te komen tegen rechterlijke uitspraken. Van een rechterlijke uitspraak staan hoger beroep en/of cassatie open; van een schikking kan uiteraard niet in hoger beroep worden gegaan. Indien in een rechterlijke uitspraak het recht - of dit nu regelend of dwingend van aard is - onjuist is toegepast, zal hiertegen met succes kunnen worden opgekomen in hoger beroep. Partijen zijn op grond van art. 7:902 BW daarentegen zelfs gebonden aan een vaststelling op vermogensrechtelijk gebied die in strijd blijkt te zijn met dwingend recht. Enkel indien ook sprake is van strijd met de goede zeden of de openbare orde, is dit anders.

Bedacht moet wel worden dat de mogelijkheid om op te komen tegen een rechterlijke uitspraak relatief kort bestaat. De beroepstermijn is in veel gevallen drie maanden. ${ }^{12}$ Als deze termijn ongebruikt verstrijkt, gaat de rechterlijke uitspraak in kracht van gewijsde en is aantasting enkel nog mogelijk door middel van de buitengewone rechtsmiddelen derdenverzet en herroeping. $\mathrm{Na}$ het ongebruikt verstrijken van de rechtsmiddelentermijn zijn partijen dus zelfs gebonden aan een uitspraak waarin recht van openbare orde onjuist is toegepast.

En al zijn partijen ook gebonden aan een vaststelling in strijd met dwingend recht, er zijn wel andere gronden waarop de rechtsgeldigheid van een schikking ter discussie kan komen te staan. Doordat een schikking neergelegd in een proces-verbaal een overeenkomst is, is zij bijvoorbeeld vernietigbaar op grond van een wilsgebrek. Een beroep op een wilsgebrek staat veel langer open dan dat van een rechterlijke uitspraak in hoger beroep kan worden gegaan - zie voor de verjaringstermijnen art. 3:52 BW. Ter afwering van een op de schikking steunende vordering of andere rechtsmaatregel kan op grond van art. 3:51 lid $3 \mathrm{BW}$ zelfs te allen tijde een beroep in rechte op de vernietigingsgrond worden gedaan. Executie op basis van het proces-verbaal waarin de schikking is neergelegd, kan als een 'andere rechtsmaatregel' in de zin van deze bepaling worden gezien. ${ }^{13}$

Wel is het de vraag of een beroep op een wilsgebrek snel zal slagen, nu een vaststellingsovereenkomst er juist toe dient om rechtszekerheid te bewerkstelligen. Aangenomen kan worden dat voor een geslaagd beroep op dwaling onvoldoende is het enkele feit dat de regeling die partijen in hun vaststellingsovereenkomst hebben neergelegd, blijkt af te wijken van hetgeen zonder de overeenkomst tussen hen gegolden zou heb-

12. Zie art. 339 lid 1, 358 lid 2, 402 lid 1 en 426 lid 1 Rv.

13. Zie Parl. Gesch. BW Boek 3, p. 237-238, waar wordt opgemerkt dat bij 'andere rechtsmaatregel' kan worden gedacht aan parate executie door de pand- of hypotheekhouder, executie op grond van een authentieke akte en derdenbeslag, enz. 
ben. ${ }^{14}$ Toch moet een beroep op dwaling niet al te terughoudend worden beoordeeld. De Hoge Raad stelt in zijn jurisprudentie de mogelijkheid om ook in geval van een vaststellingsovereenkomst een geslaagd beroep op dwaling te doen voorop. ${ }^{15}$ Dit geldt volgens de Hoge Raad in het bijzonder indien sprake is van betrokkenheid van de wederpartij bij de dwaling op een wijze als genoemd in art. 6:228 lid 1 onder a of b BW. ${ }^{16}$ Een geslaagd beroep op dwaling bij de totstandkoming van een vaststellingsovereenkomst is dus geenszins uitgesloten.

Aangezien een vaststellingsovereenkomst een wederkerige overeenkomst is, kan zij voorts op grond van art. 6:265 BW worden ontbonden wegens een tekortkoming in de nakoming. ${ }^{17}$ Stel dat partijen in een schikking neergelegd in een proces-verbaal zijn overeengekomen dat $\mathrm{A}$ een schadevergoeding van $€ 10.000$ zal betalen aan $B$. Net als bij een rechterlijke uitspraak kan B in geval van niet-nakoming besluiten tot tenuitvoerlegging over te gaan. $B$ beschikt immers over een executoriale titel. Anders dan bij een rechterlijke uitspraak kan B in plaats daarvan ook besluiten de vaststellingsovereenkomst te ontbinden. Ontbinding heeft als gevolg dat de onzekerheid die tussen partijen bestond, herleeft. ${ }^{18}$ Voor B kan ontbinding aantrekkelijk zijn indien zij, bijvoorbeeld op grond van een latere jurisprudentiële ontwikkeling, verwacht bij de rechter een veel hogere schadevergoeding te krijgen dan de $€ 10.000$ die partijen waren overeengekomen. Op grond van art. 3:311 lid $1 \mathrm{BW}$ verjaart de rechtsvordering tot ontbinding vijf jaar na de dag waarop de schuldeiser met de tekortkoming bekend is geworden en in ieder geval twintig jaar nadat de tekortkoming is ontstaan.

\subsection{Knelpunten en mogelijke oplossingen}

Zoals hierboven is gebleken, kan de geldigheid van een schikking veel langer ter discussie komen te staan dan het geval is bij een rechterlijke uitspraak. Partijen die deze onzekerheid onwenselijk vinden, kunnen haar beperken door in de schikking het beroep op ontbinding en op dwaling uit te sluiten. Art. 6:265 BW is van regelend recht. ${ }^{19}$ Ook een beding waarbij het beroep op dwaling wordt uitgesloten, wordt over het algemeen geldig geacht, al wordt wel aangenomen dat een beroep op dit beding kan afstuiten op de beperkende werking van de redelijkheid en billijkheid. Een voorbeeld waarin hiervan sprake kan zijn, is dat de partij die zich op het beding

14. Vgl. HR 15 november 1985, ECLI:NL:HR:1985:AC4400, NJ 1986/228, m.nt. W.C.L. van der Grinten (Ebele Dillema II); Asser/Van Schaick 7-VIII*2012/160-161.

15. HR 29 september 1995, ECLI:NL:HR:1995:ZC1825, NJ 1998/81, m.nt. C.J.H. Brunner ( $A B N A M R O /$ Hendriks), r.o. 3.3.3; HR 1 februari 2013, ECLI:NL:HR:2013:BY3129, NJ 2013/84 (Van Leeuwen c.s./Lips c.s.), r.o. 3.4.1.

16. HR 1 februari 2013, ECLI:NL:HR:2013:BY3129, NJ 2013/84 (Van Leenwen c.s./Lips c.s.), r.o. 3.4.1.

17. De bijzondere regeling voor ontbinding neergelegd in art. 7:905 BW is enkel van toepassing op de bindende partijbeslissing en het bindende advies.

18. Zie Asser/Van Schaick 7-VIII*2012/168. Een voorbeeld waarin een vaststellingsovereenkomst werd ontbonden, is Rb. Limburg 5 april 2017 , ECLI:NL:RBLIM:2017:3061, NJF 2017/223, Prg. 2017/176.

19. Zie Parl. Gesch. BW Boek 6, p. 1011; Toelichting Meijers, Vierde gedeelte, Boek 7, p. 1148. beroept de dwaling zelf heeft veroorzaakt. ${ }^{20}$ Helemaal voorkomen dat de schikking wordt vernietigd wegens dwaling kunnen partijen kortom niet.

\section{Gezag van gewijsde}

\subsection{Rechterlijke uitspraak versus schikking in een proces-verbaal}

Een ander verschil in werking tussen een rechterlijke uitspraak en een schikking neergelegd in een proces-verbaal hangt met de vorige verschillen samen. Beslissingen neergelegd in een rechterlijke uitspraak kunnen gezag van gewijsde krijgen. Art. $236 \mathrm{Rv}$ bepaalt dat beslissingen die de rechtsbetrekking in geschil betreffen en zijn vervat in een in kracht van gewijsde gegaan vonnis, in een ander geding tussen dezelfde partijen bindende kracht hebben. ${ }^{21}$ Indien de rechter in een in kracht van gewijsde gegaan vonnis heeft beslist dat A eigenaar is van een stuk grond, staat dit in principe ook in volgende procedures tussen partijen vast. ${ }^{22}$

Aan een schikking neergelegd in een proces-verbaal komt daarentegen geen gezag van gewijsde toe. Dit betekent dat de rechtsbetrekking die partijen met hun schikking hebben willen vaststellen, in een nieuwe procedure om verschillende redenen opnieuw ter discussie kan komen te staan. Indien partijen in een schikking bijvoorbeeld neerleggen dat $\mathrm{A}$ eigenaar is van een stuk grond, kan B in een nieuwe procedure best betogen dat $\mathrm{A}$ toch géén eigenaar is. $\mathrm{B}$ kan bijvoorbeeld stellen dat partijen nooit uitvoering hebben gegeven aan de overeenkomst en dat A de grond nooit geleverd heeft gekregen. B kan ook betogen dat de vaststellingsovereenkomst is vernietigd op grond van dwaling, zodat er geen geldige titel aan de levering aan A ten grondslag lag. Ten slotte heeft een vaststellingsovereenkomst als gevolg van de dispositieve werking geen terugwerkende kracht: pas vanaf het moment dat B ter uitvoering van de schikking de grond aan A levert, is A eigenaar. ${ }^{23} \mathrm{De}$ vraag wie vóór deze levering eigenaar was, kan in theorie kortom opnieuw ter discussie komen te staan.

\subsection{Knelpunten en mogelijke oplossingen}

Het gebrek aan terugwerkende kracht van een vaststellingsovereenkomst zou tot problemen kunnen leiden. Om de kans te verkleinen dat in het hierboven genoemde voorbeeld alsnog discussie ontstaat over de vraag wie vóór het moment van levering eigenaar van de grond was, kunnen partijen in de schikking overeenkomen dat $\mathrm{B}$ afstand doet van alle aanspraken die uit een vóór het moment van levering eventueel aan B toeko-

20. Asser/Hartkamp \& Sieburgh 6-III 2014/244; Asser/Hijma 7-I* 2012/244; Jac. Hijma e.a., Rechtshandeling en overeenkomst, Deventer: Wolters Kluwer 2016, nr. 176 (Van Dam).

21. Aan een vonnis in kort geding komt echter geen gezag van gewijsde toe; zie H.J. Snijders, C.J.M. Klaassen \& G.J. Meijer, Nederlands burgerlijk procesrecht, Deventer: Wolters Kluwer 2017, nr. 60, p. 88; HR 16 december 1994, ECLI:NL:HR:1994:AC1583, NJ 1995/213 (Kloes/Fransman), r.o. 3.3 .

22. Partijen moeten blijkens art. 236 lid $3 \mathrm{Rv}$ wel een beroep doen op het gezag van gewijsde.

23. Zie Asser/Van Schaick 7-VIII*2012/158. 
mend eigendomsrecht voortvloeien. Hoewel A niet alsnog eigenaar kan worden gemaakt over een periode in het verleden, kan B wel haar aanspraak op bijvoorbeeld schadevergoeding wegens een door $\mathrm{A}$ in die periode gemaakte inbreuk op B's eigendomsrecht laten varen. In geval van een dergelijke afstand van recht zal B over het algemeen geen belang meer hebben bij een procedure over de eigendom vóór het moment van levering.

Niet uitgesloten is dat een schikking waarbij partijen overeenkomen dat A eigenaar is van een stuk grond, hoe dan ook aldus moet worden uitgelegd dat hierin een afstand door $\mathrm{B}$ van aanspraken uit het verleden besloten ligt. Voor partijen kan het echter geen kwaad om een dergelijke afstand expliciet in hun overeenkomst op te nemen.

\section{Verjaring}

\subsection{Rechterlijke uitspraak versus schikking in een proces-verbaal}

Zoals hierboven reeds is gebleken, doen zich op het punt van de verjaring grote verschillen voor. Op grond van art. 3:324 lid $1 \mathrm{BW}$ geldt voor de bevoegdheid tot tenuitvoerlegging van een rechterlijke uitspraak een verjaringstermijn van twintig jaar. Vorderingen die voortvloeien uit een schikking neergelegd in een proces-verbaal zijn daarentegen vorderingen uit overeenkomst. Voor deze vorderingen geldt in veel gevallen op grond van art. 3:307 lid 1 BW de veel kortere verjaringstermijn van vijf jaar. ${ }^{24}$

\subsection{Knelpunten en mogelijke oplossingen}

Aangezien op grond van art. 3:322 lid 3 BW geen afstand van verjaring kan worden gedaan voordat de verjaring voltooid is, is het niet mogelijk om in de schikking een langere verjaringstermijn overeen te komen. Dat bij vaststellingsovereenkomst op grond van art. 7:902 BW kan worden afgeweken van dwingend recht maakt dit niet anders. Deze mogelijkheid bestaat namelijk alleen voor die bepalingen in een schikking die betrekking hebben op het terrein van onzekerheid of geschil. Voor de overige bedingen in de overeenkomst geldt zij niet. ${ }^{25}$ Voorts is een overeenkomst die de strekking heeft om af te wijken van dwingend recht tevens in strijd met de openbare orde en derhalve nietig. ${ }^{26}$

24. Zie HR 27 november 2015, ECLI:NL:HR:2015:3424, NJ2016/3.

25. Toelichting Meijers, Vierde gedeelte, Boek 7, p. 1141.

26. Toelichting Meijers, Vierde gedeelte, Boek 7, p. 1141-1142; PG, p. 39; HR 21 april 1995, ECLI:NL:HR:1995:ZC1711, NJ 1997/570, m.nt. C.J.H. Brunner (Schmitz/Caspers), r.o. 3.4. Zie echter ook HR 27 maart 2009, ECLI:NL:HR:2009:BH1544, NJ 2009/579, m.nt. A.I.M. van Mierlo (MSD/Euromedica), r.o. 3.6, waarin wel een opening lijkt te worden geboden om op deze manier bij vaststellingsovereenkomst een verjaringstermijn te verlengen. Dit arrest is in de literatuur sterk bekritiseerd. Zie de NJ-noot van Van Mierlo, met name nr. 5; A.C. van Schaick, NTBR 2009/33, met name nr. 4 en 6; M.M. Stolp \& M.H.J. van Maanen, 'Afgewezen: het beroep op verjaring van verbeurde dwangsommen', $M v V 2009$, met name p. 156.

\section{Een alternatieve route?}

Zoals in het voorgaande is gebleken, verschilt de werking van een schikking neergelegd in een proces-verbaal in meerdere opzichten van die van een rechterlijke uitspraak. De vraag is of partijen die willen ontkomen aan de rechtsgevolgen verbonden aan een schikking, hun schikking ook kunnen 'opwaarderen' tot een rechterlijke uitspraak. In de praktijk gebeurt het wel dat de rechter conform een schikking van partijen vonnis wijst, waarbij hij in sommige gevallen een onderhandse akte van partijen, waarin de schikking is neergelegd, aan het vonnis hecht. ${ }^{27}$ Voor een dergelijke handelwijze kan aanleiding bestaan indien partijen niet kunnen profiteren van art. 87 lid $3 \mathrm{Rv}$, maar wel graag een executoriale titel voor hun schikking zouden willen verkrijgen. Partijen weten bijvoorbeeld tijdens een comparitie nog geen overeenstemming te bereiken, maar kort daarna wel. Onder KEI lijkt dit probleem overigens opgelost: in de memorie van toelichting bij art. $30 \mathrm{~m} \mathrm{Rv}$ (nieuw) wordt uitdrukkelijk opgemerkt dat een proces-verbaal met executoriale kracht op verzoek van partijen ook kan worden opgemaakt indien partijen de schikking niet tijdens een mondelinge behandeling bereiken. ${ }^{28}$ In het verleden kwam het zoals gezegd echter wel voor dat partijen in een dergelijk geval de rechter verzochten conform een schikking vonnis te wijzen; of aan deze praktijk met de invoering van KEI een einde zal komen, moet nog worden afgewacht. De vraag is welke rechtsgevolgen toekomen aan een vonnis waarin een schikking van partijen is opgenomen. Verkrijgt de schikking hiermee wel dezelfde werking als een rechterlijke uitspraak?

Gelet op de rechtspraak van de Hoge Raad ten aanzien van art. $819 \mathrm{Rv}$ is dit sterk de vraag. Art. $819 \mathrm{Rv}$ biedt de rechter in geval van een echtscheidingsprocedure de mogelijkheid om op verzoek van de echtgenoten of van een van hen de getroffen onderlinge regelingen geheel of gedeeltelijk in de echtscheidingsbeschikking op te nemen. In een geval waarin de rechter van deze mogelijkheid gebruik had gemaakt en zijn uitspraak had gebaseerd op een overeenkomst omtrent alimentatie vervat in een convenant, betoogde de man dat het convenant van partijen in zijn geheel door de rechterlijke uitspraak was vervangen. In deze zaak bevatte het oorspronkelijke convenant een niet-wijzigingsbeding. Volgens de man was dit beding komen te vervallen doordat de rechterlijke uitspraak in de plaats van het convenant was getreden. Dit betoog werd door de Hoge Raad verworpen. Hij overwoog:

'Indien de rechter zich bij de veroordeling van de ene partij tot betaling aan de andere partij van een uitkering tot levensonderhoud conformeert aan hetgeen partijen te dien aanzien waren overeengekomen, moet in beginsel worden aangenomen dat die veroordeling geen verdere strekking heeft dan om de partij ten behoeve van wie de veroorde-

27. Zie G. van Rijssen, 'Commentaar op art. 87 Rv, nr. C.5’, in: R.H. de Bock e.a. (red.), Sdu Commentaar Burgerlijk Procesrecht, Den Haag: Sdu Uitgevers 2012, p. 254. Zie bijv. Rb. 's-Hertogenbosch (k.g.) 3 augustus 2004, ECLI:NL:RBSHE:2004:AQ9187; Rb. Almelo 18 mei 2005, ECLI: NL:RBALM:2005:AU6149.

28. Kamerstukken II 2014/15, 34059, 3, p. 73 (MvT). 
ling is uitgesproken een executoriale titel te verschaffen teneinde zonodig de nakoming in zoverre van de overeenkomst in rechte af te dwingen. Dat brengt mee dat de overeenkomst, ook voor wat betreft een eventueel daarvan deel uitmakend beding van niet-wijziging, door de veroordeling onverlet wordt gelaten. Dit is slechts anders indien uit de rechterlijke uitspraak van een verdergaande strekking blijkt. ${ }^{29}$

Het enkele feit dat de rechter de afspraken van partijen in een beschikking opneemt, betekent nog niet dat deze afspraken ook de werking van een rechterlijke uitspraak verkrijgen. Opname van het echtscheidingsconvenant in de beschikking verandert het karakter van dit convenant in principe niet: de overeenkomst van partijen wordt volgens de Hoge Raad onverlet gelaten. Net als bij een proces-verbaal is kortom niet de vorm (een beschikking van de rechter), maar de inhoud (een convenant van partijen) beslissend. ${ }^{30}$

Deze uitspraak van de Hoge Raad lijkt zich te lenen voor analoge toepassing buiten het terrein van het echtscheidingsprocesrecht. Ook in gevallen waarin de rechter vonnis wijst conform een schikking van partijen lijkt de strekking van deze veroordeling vooral te zijn om partijen een executoriale titel te verschaffen. Er is dan ook in beginsel geen reden om alle, hierboven besproken, gevolgen van een rechterlijke uitspraak aan een dergelijk vonnis toe te kennen. Partijen kunnen dus niet aan de werking van het overeenkomstenrecht ontkomen door de rechter te vragen hun schikking in zijn vonnis op te nemen. Wel is het steeds een kwestie van uitleg waarvan sprake is: wordt in het vonnis enkel de schikking van partijen neergelegd, of geeft de rechter in het vonnis een eigen oordeel? De grens tussen beide soorten vonnissen zal in de praktijk niet steeds gemakkelijk te trekken zijn.

\section{Conclusie}

Zowel een rechterlijke uitspraak als een schikking neergelegd in een proces-verbaal levert een executoriale titel op. Voor het overige bestaan echter grote verschillen in werking tussen beide. Een schikking neergelegd in een proces-verbaal is een overeenkomst, zodat de rechtsgevolgen worden bepaald door het overeenkomstenrecht. Meer specifiek is sprake van een vaststellingsovereenkomst. In dit artikel is een aantal knelpunten gesignaleerd dat voortvloeit uit dit verschil in werking en zijn suggesties gedaan om deze knelpunten te ondervangen.

Een aantal knelpunten vloeit voort uit het feit dat een vaststellingsovereenkomst 'dispositieve werking' heeft. Hierdoor wordt de door partijen beoogde rechtstoestand niet altijd 'automatisch' gerealiseerd, maar zijn in sommige gevallen uit- voeringshandelingen vereist. Dit geldt met name in geschillen rond de rechtstoestand van registergoederen. Om te voorkomen dat het verrichten van deze uitvoeringshandelingen problemen oplevert, is het voor partijen aan te raden om in de schikking al zo concreet mogelijke afspraken te maken over deze handelingen, en deze afspraken eventueel te versterken met een boetebeding. Ook denkbaar is dat de ene partij aan de andere een volmacht verleent voor het verrichten van de uitvoeringshandelingen. Als gevolg van de dispositieve werking heeft een vaststellingsovereenkomst voorts geen terugwerkende kracht. Om te voorkomen dat alsnog een geschil ontstaat over de 'oude' rechtssituatie die vóór de vaststelling tussen partijen gold, kunnen partijen in hun schikking expliciet afstand doen van eventuele aanspraken die voortvloeien uit deze 'oude' rechtssituatie.

Een ander knelpunt dat is gesignaleerd, is dat de geldigheid van een schikking nog gedurende een veel langere periode ter discussie kan komen te staan dan het geval is bij een rechterlijke uitspraak. Partijen kunnen deze onzekerheid enigszins beperken door in de schikking de mogelijkheid van een beroep op dwaling en op ontbinding uit te sluiten.

Een laatste knelpunt is moeilijk te ondervangen. De vorderingen die voortvloeien uit een schikking zullen over het algemeen eerder verjaren dan de bevoegdheid tot tenuitvoerlegging van een rechterlijke uitspraak. Aangezien op grond van art. 3:322 lid $3 \mathrm{BW}$ geen afstand van verjaring kan worden gedaan voordat de verjaring voltooid is, hebben partijen geen mogelijkheid hier verandering in te brengen.

In dit artikel is ten slotte onderzocht of partijen hun schikking ook kunnen 'opwaarderen' tot een rechterlijke uitspraak. In de praktijk gebeurt het wel dat een rechter uitspraak doet conform een schikking van partijen. Daarmee verliest de schikking echter niet het karakter van een overeenkomst. In een beschikking in het kader van art. $819 \mathrm{Rv}$ oordeelde de Hoge Raad dat de overeenkomst van partijen door opname in een echtscheidingsbeschikking onverlet werd gelaten. Voor de rechtsgevolgen maakt het kortom niet uit of een schikking is vervat in een onderhandse akte, in een proces-verbaal, of in een rechterlijke uitspraak. Een schikking is, en blijft, een overeenkomst van partijen.

29. HR 19 november 1982, ECLI:NL:HR:1982:AG4483, NJ 1983/494, m.nt. E.A.A. Luijten, r.o. 3.3

30. Zie over het karakter van een in een echtscheidingsbeschikking opgenomen convenant ook, met aanhaling van lagere jurisprudentie waarin de uitspraak van de Hoge Raad lijkt te worden miskend, P. de Bruijn \& R. Westrik, 'Convenant en echtscheidingsbeschikking: gezamenlijk gezag van gewijsde?', EB 2012/3 en EB 2013/41; P. de Bruijn \& R. Westrik, 'Convenant, echtscheidingsbeschikking en executoriale kracht', $E B$ 2013/61. 